\title{
A SURVEY OF RYEGRASS MOSAIC VIRUS AND ENDOPHYTE IN OTAGO AND SOUTHLAND
}

\author{
T.E. SMALES ${ }^{1}$, C.M. FERGUSON ${ }^{2}$, P.L. GUY ${ }^{1}$ and J.A.SHAND ${ }^{2}$ \\ ${ }^{1}$ Department of Botany, University of Otago, PO Box 56, Dunedin \\ ${ }^{2}$ AgResearch, Invermay Agricultural Centre, PB 50034, Mosgiel
}

\begin{abstract}
Twenty four ryegrass /white clover pastures throughout Otago and Southland were surveyed for the presence of ryegrass mosaic virus (RgMV),Acremonium lolii and eriophyid mites. Densities of Argentine stem weevil were measured at eight sites. RgMV was found to be widespread and was recorded from 15 locations for the first time. Infection of up to $48 \%$ of ryegrass tillers by RgMV was measured. A. lolii was also found to be widespread with levels of up to $94 \%$ recorded. Mites were found at six sites. No correlation of RgMV incidence with $A$. lolii, presence of mites or Argentine stem weevil densities was detected. A comparison of A. lolii detection by ELISA and epidermal staining was carried out. The ELISA technique appeared to have greater sensitivity.
\end{abstract}

Key words: Acremonium lolii, ryegrass mosaic virus, Argentine stem weevil, ELISA

\section{INTRODUCTION}

Ryegrass mosaic virus (RgMV) is a member of the potyvirus group of plant viruses. Ryegrasses are the most important hosts but other grasses such as cocksfoot (Dactylis glomerata L.), fescue (Festuca spp.) and annual meadow grass (Poa annua L.) can be infected (Clements et al. 1978). RgMV has a world wide distribution and is considered the most serious and widespread sap-transmissible virus infecting Gramineae in Britain (Clements et al. 1978) and Australia (Eagling et al. 1992). Its effects on pasture production in New Zealand have not been determined.

The virus causes pale green streaks in the leaf lamina and in severe cases, the leaf may show yellow flecking which is followed by necrosis and death of the tiller (Clements et al. 1978). Overseas studies indicate that RgMV infection can reduce dry matter production of Italian ryegrass (Lolium multiflorum Lam.) by up to $27 \%$ (Wilkins and Hides 1976), and by up to 50\% in perennial ryegrass (Eagling et al. 1992). Holmes (1979) also demonstrated a reduction in organic matter, carbohydrate content and digestibility of RgMV infected ryegrass. RgMV was first detected in New Zealand at a site near Dunedin in 1992 (Guy 1993a). It is not known how long the virus has been present in New Zealand and its full distribution is not known.

Eriophid mites are known to transmit at least six plant viruses including RgMV (Mulligan 1960). Abacarus hystrixNal. (Acarina: Eriophyidae) is the mite responsible for most RgMV transmission (Slykhuis 1972). A. hystrix is widely distributed in the northern hemisphere and Australia (Frost 1992) and occurs in South Africa (Salm et al. 1994). It has also been recorded in New Zealand (Guy 1993a) but its distribution is unknown. Argentine stem weevil (Listronotus bonariensis Kuschel) (Coleoptera: Curculionidae) has been shown to transmit RgMV but appears to be an inefficient vector (Smales et al. 1995). RgMV can also be transmitted by farm machinery and livestock (Catherall 1987).

The endophyte Acremonium lolii (Latch, Christenson and Samuels) in perennial ryegrass (Lolium perenne L.) is recognized as having a major impact on pasture performance in New Zealand. The relationship between plant and endophytic fungus 
is considered mutualistic with the host grass benefiting from increased plant growth (van Heeswijck and McDonald 1992) and resistance to Argentine stem weevil (Goldson and Penman 1979; Prestidge et al. 1982). The presence of endophyte may also confer a degree of protection to plants from virus diseases. Latch et al. (1985) found that the main aphid vector of barley yellow dwarf virus (BYDV), Rhopalosiphum padiL. (Hemiptera: Aphididae) avoided fescue plants (Festuca arundinaceaSchreber) infected with the endophyte Acremonium coenophialum (Morgan, Jones, and Gams). However the presence of $A$. lolii has no effect on the incidence of BYDV in perennial ryegrass (Guy 1993b). It is not known whether the presence of A. lolii confers resistance to ryegrass against infection by $\mathrm{RgMV}$.

This investigation aimed to provide data to determine the distribution of RgMV in the southern South Island and relate this to the presence of its known mite vector and Argentine stem weevil. It also investigated the relationship between incidence of RgMV and $A$. lolii infection. ELISAs (Enzyme Linked Immunosorbent Assays) were used to determine $A$. lolii incidence in the survey and this technique was compared with the more commonly used epidermal staining technique.

\section{Survey of pastures}

\section{METHODS}

Fifty ryegrass tillers were collected from each of 25 pasture sites throughout Otago and Southland (Table 1) between September and November 1995. Tillers were collected by walking in a broad diagonal zigzag across the paddock, avoiding paddock margins, and hand picking one tiller every 20 paces. The whole grass tiller including the base was taken, placed in a plastic bag and stored at $4^{\circ} \mathrm{C}$ until a standard ELISA (Agdia Indirect ELISA) was carried out to detect RgMV.

A part of each sample prepared for RgMV detection was used to determine the presence of $A$. lolii by a double antibody sandwich (DAS) ELISA specific to A. lolii (Clark and Adams 1977) with some modifications (Ian Garthwaite, AgResearch, pers comm.).

Immediately prior to the preparation of samples for the ELISAs, the adaxial surface of 20 tillers, randomly selected from each pasture, were examined under a binocular microscope for the presence of eriophyid mites.

Densities of adult Argentine stem weevil were measured at eight sites by digging $150 \times 150 \mathrm{~cm} \times 30 \mathrm{~cm}$ deep turfs from the pastures and heat extracting weevils from these in Tulgren funnels (Proffitt et al. 1993).

Data were analysed by plotting one variable against the other and exploring the relationships.

\section{Comparison of $\boldsymbol{A}$. lolii detection by ELISA and epidermal staining}

Two tillers from each of 219 ryegrass plants collected from five ryegrass / white clover (Trifolium repens L.) dominated pastures were examined for the presence of A. lolii. A 2-3 cell thick epidermal strip taken from the base of the leaf sheath of one tiller from each pair was stained with lactophenol cotton blue. This was examined for the presence of $A$. lolii hyphae under a microscope. The second tiller from each pair was tested using ELISA methods described above.

\section{Survey of pastures}

\section{RESULTS AND DISCUSSION}

The results showed that $\mathrm{RgMV}$ is widespread in ryegrass dominated pastures throughout Otago and Southland (Table 1). Of the pastures sampled, 60\% contained RgMV with the highest level recorded being $48 \%$ of tillers infected (Table 1). This is the highest level recorded to date in the South Island but a level of $56 \%$ has been reported from Kaikohe, Northland (D. Webster, pers. comm.). The results of this survey are new records for RgMV.

A. lolii was also found to be widespread (Table 1 ). The only pasture where A. lolii was absent was at Invermay. In this case the paddock had been sown with endophyte free Grasslands Manawa ryegrass (L. (perenne x multiflorum) $\mathrm{x} L$. perenne). The other Invermay site was also a Grasslands Manawa pasture and the $2 \%$ of tillers with $A$. lolii 
here were probably from volunteer perennial ryegrass plants. All other sites were perennial ryegrass based and the levels of infection ranged from 12-94\% (Table 1). This result supports the findings of Ferguson et al. (1994) who also showed widespread occurrence of A. lolii and similar levels of infection throughout Otago and Southland. No negative relationship was found between the levels of RgMV and A. lolii in the pastures. Excluding tillers from the Invermay sites, $78 \%$ of tillers infected with RgMV were also infected by $A$. lolii. These results suggest that, unless infection by RgMV occurs in seedlings before $A$. lolii expresses itself, the presence of $A$. lolii in a ryegrass plant does not confer resistance against RgMV infection. The high numbers of tillers infected with both organisms could indicate that there may be a positive relationship between RgMV and A. lolii. However, the results from the Invermay sites show infection by RgMV in the absence of $A$. lolii, and the majority of tillers at the other sites containing endophyte were not infected by RgMV.

Eriophyid mites were detected at only six of the sites sampled (Table 1). Identification of these mites to species level is difficult and it was not possible to confirm identification as A. hystrix. The most common eriophyid mite in southern South Island pastures is Aculodes mckenziei (Guy and Gould 1996) which has not as yet been shown to transmit RgMV. These two mites are difficult to distinguish from each other. This study failed to establish any link between the presence of eriophyid mites and RgMV.

TABLE 1: Incidence of RgMV and Acremonium lolii, densities of adult Argentine stem weevil (ASW) and eriophyid mites in Otago and Southland ryegrass pastures.

\begin{tabular}{lrccc}
\hline Location & RgMV $(\%)$ & A. lolii $(\%)$ & ASW/m & Mites/20 tillers \\
\hline Ikiwai & 30 & 70 & - & 0 \\
Ophir 1 & 28 & 44 & 11 & 6 \\
Ophir 2 & 4 & 79 & 38 & 2 \\
Ophir 3 & 12 & 29 & 7 & 16 \\
Ophir 4 & 20 & 94 & 16 & 5 \\
Kyeburn & 4 & 68 & 47 & 0 \\
Redbank & 13 & 43 & - & 7 \\
Palmerston & 0 & 30 & - & 0 \\
Sutton 1 & 20 & - & - & 0 \\
Sutton 2 & 27 & 70 & 56 & 0 \\
Invermay 1 & 25 & 2 & 34 & 0 \\
Invermay 2 & 48 & 0 & 9 & 0 \\
Raes Junction & 2 & 92 & - & 0 \\
Puketi & 0 & 41 & - & 0 \\
Milton & 0 & 30 & - & 0 \\
Balfour & 7 & 27 & - & 0 \\
Waipahi & 2 & 55 & - & 0 \\
Riversdale & 0 & 12 & - & 0 \\
Mossburn & 0 & 15 & - & 0 \\
Otautau & 29 & 63 & - & 0 \\
Balclutha & 0 & 14 & - & 0 \\
Woodlands & 0 & 70 & - & 0 \\
Owaka & 0 & 63 & - & 0 \\
Tokanui & 0 & 39 & - & 0 \\
Stewart Island & 0 & 89 & - & \\
On & 0 & & & 0
\end{tabular}

Argentine stem weevil was found at all sites sampled (Table 1) but no correlation was found between weevil densities and levels of infection by RgMV. Although Smales et al. (1995) showed Argentine stem weevil was capable of transmitting 
RgMV, it appeared to be an inefficient vector and the current result is not, therefore, unexpected.

\section{Comparison of $\boldsymbol{A}$. lolii detection by ELISA and epidermal staining}

Of the 219 tests carried out comparing the two methods of $A$. lolii detection, the techniques agreed on $64 \%$ of the samples. The ELISA detected A. lolii on $26 \%$ of tests where it was not detected by epidermal staining while the reverse applied on only five occasions. Seventeen tests gave unclear ELISA results due to high background interference. Assuming that endophyte occurs in all tillers in the plant, it appears that the ELISA is a more sensitive method than epidermal staining. This is partly because it is quite conceivable that fungal hyphae may be absent from the epidermal sample even though it is present in the plant.

\section{ACKNOWLEDGEMENTS}

The authors would like to thank Dr. I. Garthwaite, AgResearch, for allowing us to use his ELISA protocol and anti-serum, the farmers who allowed us access to their properties, P.D. Johnstone for statistical advice, G.S. Wijkstra, R.A. Lister, A.S. Cresswell and A.A. Evans for technical support and B.I.P.Barratt for critical comment on the manuscript. This work was partially funded by The Foundation for Research, Science and Technology.

\section{REFERENCES}

Catherall, P.L., 1987. Effects of barley yellow dwarf and ryegrass mosaic viruses alone and in combination on the production of perennial and Italian ryegrass. Plant. Path. 36: 73-78.

Clark, M.F. and Adams, A.N., 1977. Characteristics of the microplate method of enzyme linked immunosorbent assay for the detection of plant viruses. J. Gen. Virol. 34: 475-483.

Clements R.O., Gibson R.W., Henderson I.F. and Plumb R.T., 1978. Ryegrass: pest and virus problems. ARC Research Review 4:51-54.

Eagling, D.R., Villalta, O. and Sward, R.J., 1992. Host range, symptoms and effects on pasture production of a Victorian isolate of ryegrass mosaic potyvirus. Aust. J. Agric. Res. 43: 1243-1251.

Ferguson, C.M., Evans, A.A., Shand, J.A. and Barratt, B.I.P., 1994. Factors affecting the distribution of Listronotus bonariensis (Kuschel) (Coleoptera: Curculionidae) in Otago and Southland. Proc. N.Z. Weed and Pest Control Conf. 47: 279-281.

Frost W.E., 1992. Aspects of the population ecology of Abacarus hystrix Nalepa (Acarina: Eriophyidae) in South Australian dairy pastures.Proc. Fifth Aust. Appl. Ento. Conf.

Goldson, S.L. and Penman D.R., 1979. Effect of time of sowing on Argentine stem weevil (Hyperodes bonariensis) damage in autumn-sown Tama ryegrass. N.Z. J. Agric. Res 22: 367-371.

Guy, P.L., 1993a. First record of ryegrass mosaic virus and its mite vector Abacarus hystrix (Nal.) in New Zealand. N.Z. J. Agric. Res. 36: 377-379.

Guy, P.L., 1993b. Barley yellow dwarf viruses in Japanese pasture grasses and lack of correlation with the presence of fungal endophytes. Plant. Path. 42:1-5.

Guy, P.L and Gould, D.M., 1996. Aculoides mckenziei (Acarina :Eriophyidae) newly recorded in New Zealand and its association with other eriophyids in South Island pastures. N.Z. Entomol: (in press).

van Heeswijck, R. and McDonald, G., 1992. Acremonium endophytes in perennial ryegrass and other pasture grass in Australia and New Zealand.Aust. J. Agric. Res. 43:1683-1709.

Holmes, S.J.I., 1979. Effect of ryegrass mosaic virus on the quality of perennial ryegrass. Ann. Appl. Bio. 91: 75-79.

Latch, G.C.M., Christensen, M.J. and Gaynor, D.L., 1985. Aphid detection of endophyte infection in tall fescue. N.Z. J. Agric. Res. 82:129-132.

Mulligan, T.E., 1960. The transmission by mites, host -range and properties of ryegrass mosaic virus. Ann. Appl. Bio. 48: 575-579. 
Prestidge, R.A., Pottinger, R.P. and Barker, G.M., 1982. An association of Lolium endophyte with ryegrass resistance to Argentine stem weevil. Proc. N.Z. Weed and Pest Conf. 35: 119-122.

Proffitt, J.R., Ferguson, C.M., McNeill, M.R., Goldson, S.L., Macnab, H.R. and Barratt, B.I.P., 1993. A Comparison of sampling methods for adult Listronotus bonariensis (Kuschel). Proc. 6th Aust. Conf. Grassl. Invert. Ecol: 67-72.

Salm, S.N., Rey, M.E.C. and Wolfson, M.M., 1994. A South African isolate of ryegrass mosaic virus. Plant. Path. 43: 708-712.

Slykhuis, J.T., 1972. Ryegrass mosaic virus. C.M.I./A.A.B Descriptions of Plant Viruses. No 86.

Smales, T.E., Ferguson, C.M and Guy, P.L., 1995. Invertebrate pests of pasture as potential plant virus vectors. Proc. 48th N.Z. Plant Prot. Conf.: 194-198.

Wilkins, P.W. and Hides, D.H., 1976. Tolerance to ryegrass mosaic virus, its assessment and effect on yield. Ann. Appl. Bio. 83: 399-405. 